\title{
Assistance of the Youth Organization Community in the Construction of an Integrated Road as an Artificial Recharge for the Slopes of Mount Manglayang through a Participatory Action-Research Approach in Babakan Cikeruh Village
}

\author{
Riyanto Adji 1, Haris Herdiansyah'2, Teuku Rezasyah ${ }^{3}$ \\ 1,2 President University, ${ }^{3}$ Universitas Padjadjaran Bandung \\ Email: riyanto.adji@president.ac.id
}

\begin{tabular}{|c|c|}
\hline Article History: & Abstract: The purpose of community service is to \\
\hline Received: April $4^{\text {th }} 2021$ & assist youth in Babakan Village, Cikeruh, Cimekar \\
\hline Revised: Aug 11 th 2021 & Village, Cileunyi Bandung in the Construction of \\
\hline Accepted: Nov 30th 2021 & $\begin{array}{l}\text { Integrated Roads as Artificial Recharges on the } \\
\text { Slopes of Mount Manglayang. The community }\end{array}$ \\
\hline Keywords: & $\begin{array}{l}\text { service method uses participatory action } \\
\text { research. The results of this community service }\end{array}$ \\
\hline $\begin{array}{l}\text { Community } \begin{array}{r}\text { assistance, } \\
\text { Integrated }\end{array} \text { environmental }\end{array}$ & have increased youth participation in the \\
\hline road, Participatory action & construction of roads with a length of $50 \mathrm{~m}$ and a \\
\hline research, Artificial recharge & $\begin{array}{l}\text { an artificial addition to dug wells. This activity is } \\
\text { carried out independently with community funds }\end{array}$ \\
\hline
\end{tabular}

\section{Introduction}

The formation of a village comes from a very long journey and its development was influenced by the supporting potentials that exist around the village. As happened in Cimekar Village, Cileunyi District, Bandung Regency, where at the beginning, the village was a plantation on the slopes of Mount Manglayang, and along with population growth and population distribution, the plantation area turned into a village, which is increasingly growing in population and wider area. The position of Cimekar village is very strategic because it is located close to the center of education, which is flanked by several well-known universities such as the Bandung Institute of Technology (Jatinangor campus), Padjadjaran University (Jatinangor campus) and Sunan Gunung Djati State Islamic University, Bandung. Other potentials owned by Cimekar village that close to shopping centers in the Jatinangor and Cileunyi areas, close to the West Java bonded integrated industrial area in the Cicalengka-Rancaekek area, Bandung1. The coverage area of Cimekar village is very wide, arround $\pm 471,705$ ha covering 5 hamlets, with an

1 Riyanto Adji, "Pemanfaatan Sampah Non Logam Untuk Metode Artificial Recharge," in In Monograph, Edited by President University Press (Bekasi, West Java: President University, 2020), 21-22. 
administrative area of $32 \mathrm{RW}$ and $175 \mathrm{RT}^{2}$, consists of 20 villages and has \pm 14 housing complexes.

The size of the area will have an impact on the complexity of the problems in the area, and in order for assistance in Cimekar village to be directed, the area of choice is the Kampung Babakan Cikeruh area. Administratively, Babakan Cikeruh village is located in RW 14 with 4 RTs in charge, and the problems that exist in the village are also varied, ranging from juvenile delinquency, environmental management, economic problems and many other social problems. To solve these problems, it is necessary to prioritize problem solving, and the main priority that needs special attention is the problem of youth and environmental management in RT 01 RW 14, based on the results of previous studies, data shows that the number of distribution of households in RT 01 RW 14 is as many as 70 families.

The first problem that occurred in RT 01 RW 14 was juvenile delinquency caused by the low level of education and the lack of productive activities, so that they became undirected and tended to make the community restless. In general, the area of RT $01 \mathrm{RW}$ 14 of Kampung Babakan Cikeruh has a poor record, especially regarding the youth, where they have bad habits that disturb residents. The juvenile delinquency rate is quite high, lacks positive activities, and some are even used to psychotropic abuse.

Based on the researcher's interview with Mr. US (pseudonym) As a community leader in Babakan Cikeruh Village, this juvenile delinquency has been going on for a long time, and has occurred from generation to generation. The main problem lies in the low level of youth education and low motivation in school. Coupled with low socio-economic conditions, poverty worsens the situation of teenagers here to develop because of the limitations in terms of the economy. Mr. US added that many teenagers only had a junior high school education because apart from low learning motivation, their parents were also required to help earn money, so school was not of much importance to either the teenager or his family.

In addition, the researcher also conducted an interview with Mr. AM (pseudonym) as a former RT teacher who stated that the use of drugs among village youth had also started to bloom. "Nelling" is an activity that is often done by teenagers because it is relatively cheap and affordable, besides taking some medicines that can be purchased at the nearest stall or pharmacy with high doses to get the results of the chemical reactions of these drugs also often occur and it is very dangerous for life. Village youth. The information they get from word of mouth or the internet era, they can see it on the internet and then imitate it.

2 Badan Pusat Statistik Bandung, Cileunyi Regency In Figures 2020 (Bandung: Badan Pusat Statistik Kabupaten Bandung, 2020). 
Theoretically, youth is an individual who is experiencing physical growth and development that is good and strong, as well as psychologically undergoing emotional development in the search for his identity as a strong and resilient soul, so it can be said that youth is a potential human resource for future ${ }^{3}$. Along with the changing of times, there are many changes that affect the lives of young people, one of which is the social aspect where this aspect becomes a medium of socialization, a medium for thinking and a media for solving problems. This change in social style greatly affects the mindset, emotions that tend to be arrogant, so they are easily influenced by outside cultures that are not cultures that are explored based on local wisdom. The free association has resulted in many abuses and violations of ethics and norms, such as technological advances, which should have made it easier for them to add insight or exchange information, instead become a medium for the emergence of immoral acts that should not be carried out as a country that adheres to eastern customs.

In general, youth have intellectual maturity, creativity, self-confidence, innovativeness, dynamic, courageous, optimistic, independent, disciplined, have a high spirit of patriotism and nationalism as well as the ability to master Science and Technology because youth have spiritual potential which becomes the main driving force for youth when believe in something, so that youth will give everything they have and are willing to do it sincerely without expecting anything in return ${ }^{4}$. Another potential that exists in youth is intellectual potential, because they have strong analytical power supported by scientific specializations studied to make youth critical of intellectually based, besides that youth also have emotional potential, because they have courage, enthusiasm, and willpower that is always tempestuous, supported by with the physical potential of youth is at the peak of strength.

In the view of youth, the order of values and norms is considered a barrier to free expression so that the real steps taken are to fight against the order of values and norms, this is done because the feeling of inferiority is called old-fashioned or outdated. Indeed, technological progress cannot be blamed for the impact of shifting orders, ethics and norms in society, resulting in abuse and deviations committed by the younger generation $^{5}$, and basically technology will be useful if it is introduced and directed to the younger generation. Properly and correctly, so that they will know and understand very well that technology actually really helps the progress of thinking of the younger generation for their future.

${ }^{3}$ Gede Mangku Mertayasa, “Peran Pemuda Dalam Pembangunan.," Kesejahteraan Rakyat Pemerintah Kabupaten Buleleng (Buleleng, November 2020).

${ }^{4}$ Vhera Monicha, "5 Peranan Pemuda Indonesia Sebagai Generasi Penerus Bangsa," LPMGS UNSRI (LPMGS UNSRI) (Palembang, 2019).

5 Dicky Eko Prasetyo, "Pemuda Transformatif Untuk Mewujudkan Indonesia Emas Tahun 2045," ResearchGate, 2020. 
One of the results of research conducted by the Institute for Development of Economic and Finance (INDEF) states that the success of the digital economy at this time is actually mostly driven by millennials, meaning this shows that if technology is introduced properly, it will be profitable according to the needs of the times ${ }^{6}$, which is different from what happened in the service area, where many young people are less precise in utilizing technological advances, one of which is in the use of gadgets. Having a smartphone is actually used for online games and social media, this is very unfortunate and therefore, it is necessary to make efforts to direct youth to positive community activities that can benefit the environment.

Eliminating addiction to gadgets is not easy and requires a process, therefore we need to make efforts to minimize the addiction of teenagers and young people to be addicted to gadgets, because addiction to gadgets turns out to have an effect on physical and mental problems of teenagers and young people, this is corroborated by the results of several studies conducted quoted by Newport Academy which states that addiction to gadgets has the same effect as addiction to drugs because it directly attacks the brain ${ }^{7}$. One effort to reduce the problem of the younger generation being addicted to gadgets is by involving them in various positive youth activities such as youth organizations, sports activities, or assisting in realigning administrative data in the environment where they live ${ }^{8}$.

The second problem is the problem of environmental management, where in RT 01 RW 14 Kampung Babakan Cikeruh does not yet have proper RT environmental roads. When viewed in terms of its potential, this village has a lot of potential for natural resources and potential human resources, especially for the youth, but it has not been utilized optimally, and if this potential is managed properly, the problem of providing infrastructure in the form of environmental roads can be realized ${ }^{9}$. Therefore, it is necessary to take real action to take advantage of the potential of the area it has. The first and main step in this problem is through mentoring and empowering youth / youth youth organizations in increasing their role for regional development. It is not as easy as we imagine in directing and building the younger generation as the successors of regional progress, but we must be optimistic that what we prepare will be able to achieve maximum results.

In the process of mentoring and empowering youth in RT 01 RW 14 Kampung Babakan Cikeruh, The method used is the Participatory Study-Action method ${ }^{10}$, The

\footnotetext{
6 "Milenial Menjadi Kunci Kesuksesan Ekonomi Digital. Ekonomi Bisnis," Koran Sindo, last modified 2019, Sindonews.com.

${ }^{7}$ Amelia Riskita, “Cara Mengatasi Kecanduan Gadget Pada Remaja, Orang Tua Wajib Tahu! Informasi Diatas Lima Tahun," Orami.Co.Id, last modified 2021, orami.co.id.

${ }^{8}$ Siswanda and Hetifah Sjaifudian, "Kemajuan Teknologi Sebagai Katalisator Pergerakan Pemuda Di Era Digital," Hetifah.Id (Hetifah.Id), last modified 2019, hetifah.id.

${ }_{9}$ Adji, "Pemanfaatan Sampah Non Logam Untuk Metode Artificial Recharge."

${ }^{10}$ Ravik Karsidi, KAJI TINDAK: Bentuk Aplikasi Pemberdayaan Masyarakat Oleh Perguruan Tinggi
} 
selection of the Participatory Study-Action method because it prioritizes Participatory Learning and Action (PLA) where we invite and direct the community to jointly think about how to advance their role in regional infrastructure development, so that participatory action-reflection arises, and if there are obstacles in its implementation, then a participatory review can be carried out until a road is obtained exit. In this participatory study, all residents are in the same position, so that no party has hegemony/control in their regional development planning ${ }^{11}$.

The problems of youth and infrastructure development problems that occur in Kampung Babakan Cikeruh, if they are collaborated using the participatory study-action method, will produce a good outcome, namely productive youth who can help develop regional facilities because youth are the wheels of change for a region. Based on the results of discussions with the management of RT 01 RW 14 Kampung Babakan Cikeruh, infrastructure problems in the form of RT environmental roads are a priority, because apart from the condition, most of them are still original land. According to the head of the RT, the need for decent neighborhood roads is a high priority because with good and proper road access, the ease of other accesses will be easily realized. The head of RT 01 also added that the proposal for road construction/repair in RT 01 had long been submitted to the Village Government, but until now the assistance for repairing environmental roads has not yet arrived. As time shifts, the increase in the number of people crossed by the road is increasing, so that slowly the number of beneficiaries is increasing, besides that the cleanliness and beauty of the area is also a priority, because as long as the road is still original land, the habit of littering will continue. Therefore, it is hoped that if the road has been built/improved, the behavior of littering will be reduced because of shame.

The determination of the priority for the development of the RT Kampung Babakan Cikeruh neighborhood road is based on submissions from all residents who want a decent environmental road, the strong reason is to compare it with other areas that are able to have good and decent road access, and from this desire, mentoring and empowering youth for development The area is one way to provide solutions to problems that exist in RT 01 RW 14 Kampung Babakan Cikeruh, namely the participatory studyaction method where planning, implementation, supervision, utilization/management and maintenance are carried out in a participatory manner from all residents ${ }^{12}$. The real step in this participatory action study, the author invites the youth and community of RT 01 RW 14 Babakan Cikeruh Village to join hands and work together to realize the improvement of the RT environmental road. The initial steps taken in mentoring and

(Surakarta: UNS (Sebelas Maret University), 2008).

${ }^{11}$ Muhammad Rijal, "Metode Perencanaan Partisipatif Dalam Membangun Masyarakat," Academia (Academia.Edu), 2019.

12 Kementerian Pekerjaan Umum dan Perumahan Rakyat, Petunjuk Pelaksanaan Program KOTAKU Tingkat Kelurahan/Desa (Jakarta, 2018). 
empowering the youth of RT 01 RW 14 Kampung Babakan Cikeruh include recording all matters related to the construction/repair of the environmental road, starting from how the condition of the environmental road that you want to improve at this time, and why the road The RT environment must be built/improved, in addition to that the targets, aims and objectives of the RT environmental road repair must be clear, so that the construction/repair that will be implemented will have a significant impact on the surrounding community.

The results of direct field observations show that the condition of the RT environmental road is in front of the main village road, initially it was an empty land that was used as a garden by local residents, but along with the population growth of the community members of RT 01 RW 14 Babakan Cikeruh village and the increasing number of immigrants, the land changed its function into a residential area which is increasing year by year. The increasing population in the area of RT 01 RW 14 Kampung Babakan Cikeruh Cimekar Village is not balanced with good road access, this is evidenced by the condition of the roads which are still original land. Another reason that can be taken into consideration for the construction/repair of the RT neighborhood roads is the large number of children playing along the RT neighborhood roads, which raises concerns about the safety and comfort of children's playing. In addition to road conditions that are still dirt, the road surface is also uneven so it is very dangerous for children if there are vehicles that enter and leave the neighborhood road.

The increasing population growth around the location of the RT neighborhood road that you want to build/repair, is another reinforcing reason, because if the RT neighborhood road is built/repaired, the number of beneficiaries who will be able to feel directly if the environmental road is repaired will be greatly assisted in carrying out all their activities. , an improvement in terms of the economy because it will be easier for itinerant traders to go through this road, because initially it was only on village roads. Another supporting reason is in terms of environmental health, where when the condition of the road is still original soil, a lot of garbage is scattered because of how to dispose of garbage carelessly, or because it is pushed by the wind or because it is played by children. the impact of scattered garbage, but with the construction/repair of the RT neighborhood road, it is hoped that the environment will be clean because the road is no longer original land, so that the community members do not throw garbage carelessly because they are ashamed to pollute the roads that have been built/repaired.

Another problem that occurred at the planning location was the habit of residents throwing household waste water into the section, so that the conditions around the road became muddy, smelled and became a breeding ground for mosquitoes, and this became the gossip of some residents, but were unable to provide a solution. The problem of household wastewater can be solved by making infiltration wells, but this cannot be 
realized because some houses that dispose of household wastewater are reluctant to build infiltration wells, citing limited funds, besides that, another reason is that they focus on environmental management. It is the job of the RT management, not their job.

Based on the explanation above, the problem is increasing, namely the construction/repair of RT environmental roads and the procurement of household wastewater infiltration wells. Considering the limited land for infiltration wells, the planning of infiltration wells becomes an integral part of road construction/repair, meaning that infiltration wells will be built under the built/repaired environmental road. This type of infiltration well functions as an artificial recharge for dug wells owned by residents of the surrounding community, because most of the residents' clean water comes from dug wells ${ }^{13}$.

After the planning for the construction/repair of roads that is integrated with infiltration wells as an alternative solution for artificial recharge is agreed upon, the next step is to find human resources who can help put the plan into a paper. The results of the on-site review revealed that there were very few human resources capable of helping to put the plan into a proposal form. Proposals for the proposed development/repair of RT environmental roads are the main obstacle in the regional development process in RT 01, and this is a challenge to provide training on the preparation of proposals for infrastructure activities to youth in RT 01 RW 14.

In assisting the preparation of proposals, youth youth groups are directed how to prepare good proposals. A good proposal is a proposal that contains the contents of the name of the activity, the background of the reasons why the activity must be carried out, what the aims and objectives of the activity are, the objectives, an overview of the location and its potential, the types of work to be carried out, the volume of work, data needs materials, time of implementation, arrangement of activities, composition of the committee, cost estimation, offer of cooperation and closing ${ }^{14}$. The results of the assistance in the preparation of this proposal resulted in proposals regarding the construction/repair of roads that are integrated with infiltration wells, and several things that need to be considered and emphasized to youth youth and communities in RT 01 RW 14 Kampung Babakan Cikeruh are how to raise funds to finance the construction/repair of environmental roads. RT if the funds do not come from the village government, besides that it is also necessary to emphasize how to explore the self-help contributions of local residents because they are direct beneficiaries of the improvement of the RT environmental road, so that the dream of having a good RT environmental road can be realized.

13 Adji, "Pemanfaatan Sampah Non Logam Untuk Metode Artificial Recharge."

14 BPD Desa Sindangraja, Contoh Proposal Peningkatan Infrastruktur Perdesaan (Bantuan Provinsi Jawa Barat TA 2012) (Jawa Barat, 2012). 
Based on the explanation above, it is hoped that this service will produce an output, namely the creation of empowered youth who are able to explore the potential of natural resources and human resources in the environment around them, and the potential of natural resources owned around the neighborhood of RT 01 RW 14 is that there is a supermarket which is a shopping center. Communities around Cibiru - Cileunyi, besides supermarkets, there are also many office centers such as banks and community businesses, both macro and micro.

With regular mentoring and empowerment of youth youth organizations, it is also hoped that youth youth organizations who are empowered will not only be able to explore the potential of their area, then develop proposals for proposed activities, but also be able to create youth who are empowered and able to seek and explore sources of funds from outside the neighborhood of RT 01, by take advantage of the potential advantages of the region owned, so that the expected RT environmental road can be realized, and the realization of the RT environmental road also does not mean the task of mentoring youth empowerment is complete, but it is necessary and obliged to assist youth in compiling accountability reports for activities that have been carried out to residents the community as a form of transparency to the community members because in the accountability report there is a history of work implementation starting from preconditions, implementation and post-conditions. In addition, the accountability report also serves as a transparent medium for the use of funds, from the source of the funds to where they are spent and what to spend. With the preparation of an activity accountability report, it can also be used as an evaluation material for an activity that has been carried out, whether the activity is according to plan or vice versa, so that it can be used as a benchmark for the next activity ${ }^{15}$.

\section{Methods}

To realize the wishes of the residents of RT 01 RW 14 Babakan Cikeruh Village, Cimekar Village, Cileunyi District, Bandung, the author uses the Participatory Action Study approach in the form of mentoring and empowering youth youth groups. This method builds a casuistic approach by combining research and action in solving problems 16 with the hope of creating new knowledge as a way of solving problems in life in society ${ }^{17}$, so it needs to be equipped with a conceptual framework that the background to the problem at the location of service. By using this method, the author becomes part of the youth youth organization itself, so that it merges with the youth youth organization

15 GreatDayHR., "Ini Pentingnya Laporan Pertanggungjawaban” ((Info\&Update), 2020).

16 Judy McKay and Peter Marshall, "The Dual Imperatives of Action Research," Information Technology \& People (2001).

17 Max Elden and Rupert F Chisholm, "Emerging Varieties of Action Research: Introduction to the Special Issue," Human relations 46, no. 2 (1993): 121-142. 
in RT 01 RW 14 Kampung Babakan Cikeruh and collaborates with community members to find solutions to the problems they face. This participatory study-action method led researchers to different research, where the youth of RT 01 RW 14 Kampung Babakan Cikeruh were not used as objects, but as partners in solving problems that occurred in the field. Placing youth youth groups in RT 01 RW 14 Babakan Cikeruh Village, Cimekar Village as a partner, provides a great opportunity for the author to further understand the conditions in the field, so that the output is the realization of the wishes of the community members in accordance with the local wisdom that applies at the service location, namely Karang Youth cadets who can contribute to regional development ${ }^{18}$.

The application of the principle of participatory study-action in empowering youth youth organizations at the service location, the author refers to the steps ${ }^{19}$ as follows: first, the introduction of needs that are problems in the community, and the introduction of regional potentials and awareness of the citizens of the importance of these needs for the environment. , so that preliminary analysis and reflection on the situation can be carried out. Second, formulate the problem and determine priorities based on the needs and potential of the area owned. Third, identify alternative solutions or develop ideas through brainstorming at the service location. Fourth, choose alternative solutions for the most appropriate problems by taking into account the general effectiveness of these solutions, the availability and capabilities of resources, so that they can apply self-help solutions. Fifth, planning activities as outlined in a proposal for concrete activities through various discussion media such as interviews, FGDs, sharing. Sixth. Implementation of organizing activities, this is a follow-up to the results of planning activities that have been stated in an activity proposal, so that it can lead to institutional development both within the RT, RW and youth organizations. Seventh, monitoring and directing activities that aim to provide ongoing assistance so that the plans that have been implemented can run as expected so that the output is clear and measurable. Eighth, conduct an evaluation and follow-up plan, in this activity as a measuring tool in participatory assistance that has been implemented, so that we will know that in terms of empowerment there is a paradigm shift or not and in terms of activities whether the benefits can be felt by all residents. Theoretically, the Participatory Action Research strategy that will be carried out can be described as follows

18 Rambo Cronika Tampubolon, "Participatory Action Research (PAR)," LBH Jakarta, last modified 2013, https://bantuanhukum.or.id/participatory-action-research-par/.

${ }_{19}$ Ravik Karsidi, "Paradigma Baru Penyuluhan Pembangunan Dalam Pemberdayaan Masyarakat," Mediator: Jurnal Komunikasi 2, no. 1 (2001): 115-125. 


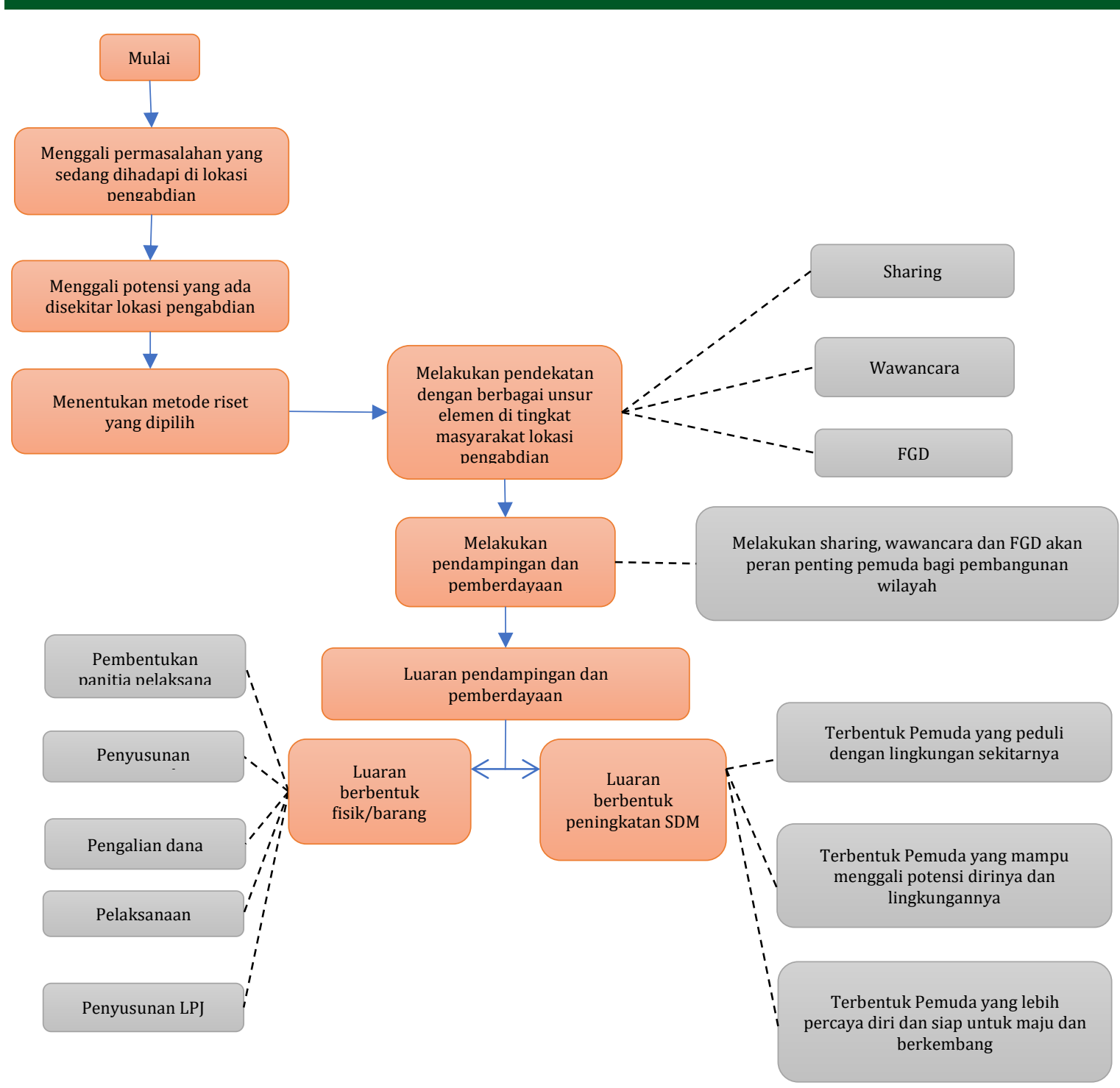

Figure 1. Flowchart of the Mentoring and Empowerment Plan for Youth in Service Locations

Based on the flowchart above, it is clear that the main movers in this participatory study-action method are youth youth organizations in RT 01 RW 14 Babakan Cikeruh Village, Cimekar Village, and the method that must be used as a concrete manifestation of the Participatory Action Research What the author does at the service location includes identifying problems at the service location, understanding problems in the field, and solving real problems by carrying out an activity whose output can be felt directly by the community, then reflecting on what has been achieved. Real steps to identify and understand problems in the field, socialization was carried out by youth youth groups about the benefits and importance of RT environmental roads for local residents, this socialization was carried out with community recitation media and RT meetings ${ }^{20}$.

${ }^{20}$ Agus Afandi, Mohammad Hadi Sucipto, and Abdul Muhid, Modul Participatory Action Research (PAR) Untuk Pengorganisasian Masyarakat (Community Organizing) (Lembaga Penelitian dan Pengabdian 
At the time of socialization, it was explained in detail about the importance of the road for social life, besides that it was also explained the benefits of the existence of the road for social life. Access to the regional economy will be smooth if the road conditions are decent, in addition to good road conditions it also shows the residents' concern for the importance of spatial planning for their area, as well as maintaining environmental cleanliness because if the road is still in its original soil condition it tends to be dirty and becomes a source of disease and when the season is dry. The dry season becomes very dirty because the soil becomes dusty. The results of the explanation about the importance of roads and the benefits of roads for community members, aroused the enthusiasm of RT administrators and residents at service locations to immediately prioritize that roads located in block A, RT 01 RW 14, should be planned and implemented as soon as possible.

After the awareness of the community members at the service location is aroused and enthusiastic, the next step is to describe the determination of the type of road construction/repair to be selected, because the determination of the type of road will determine the costs to be used in the construction process, in addition to the type of maintenance of the type of road to be built. Repairs also need to be taken into account, so that residents are able to measure the level of funding capabilities owned by local residents by paying attention to the potentials that exist around the service location. The results of the socialization of determining the type of road based on the results of the joint meeting, the type of environmental road selected was concrete rebate with an average road width of $3 \mathrm{~m}$ and a length of $50 \mathrm{~m}$.

In order for the planning of road construction/remediation to measure its usefulness for residents at the service location, the next step is youth youth groups in collaboration with RT management to collect data on how many beneficiaries will feel directly and indirectly if the environmental road block A RT 01 RW 14 materialized, and based on the results of data collection conducted by the author and RT administrators at the service location, data on prospective direct beneficiaries was obtained as many as 65 families consisting of 225 men and women. Meanwhile, the indirect beneficiaries cannot be mentioned because they are residents outside RT 01 RW 14, but always carry out their activities in the RT 01 environment, such as traveling vendors, co-workers of RT 01 residents, and community members who are in the neighborhood of RW 14 who are neighbors. From RT 01, with the recorded number of beneficiaries, it is very supportive to immediately carry out the construction/repair of the environmental road block A RT 01 . Broadly speaking, the coverage of beneficiaries can be shown in Figure 1 below.

kepada Masyarakat, UIN Sunan Ampel Surabaya, 2016). 


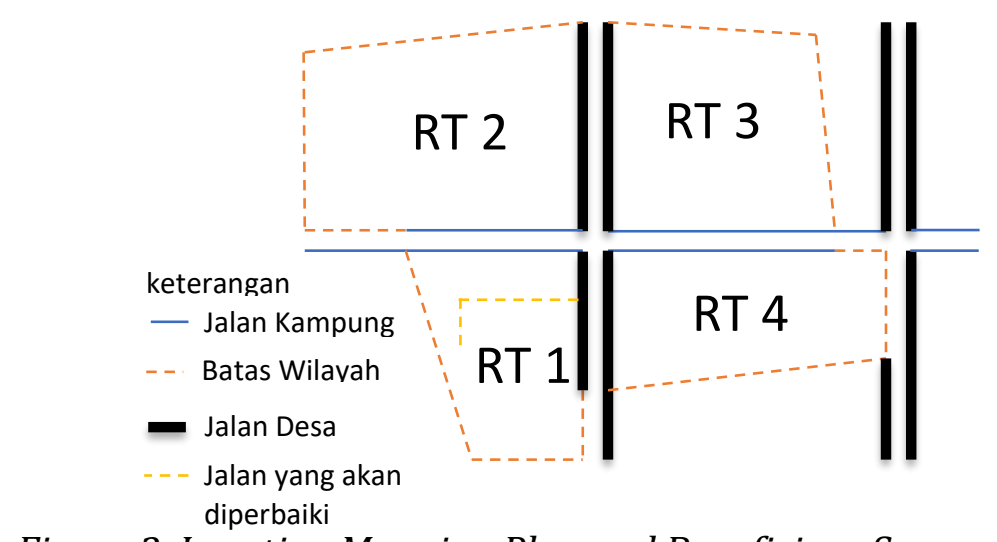

Figure 2. Location Mapping Plan and Beneficiary Scope of RT 01 Road Development/Repair

So that community service in RW 14 Kampung Babakan Cikeruh and the wishes of the community members of RT 01 can be realized, the next as a concrete form of Participatory Action Research is to provide training on proposal preparation. In planning the preparation of the proposal, the author provides assistance with several representatives of youth youth groups who have been appointed by the RT management. Important things that need to be prepared in the preparation of the proposal include the function of the proposal itself, namely as a plan that is outlined in a design, and the design must contain the title of the activity, the background of the RT environmental road development/repair plan, in this section explain the strong reasons why the activity needs to be carried out, the objectives and expected benefits of the activity. After the background of the reason for the need for the activity is explained in detail, the next step is an explanation of the activities to be carried out complete with the plan for implementing the activities (schedule) starting from pre-conditions, implementation, to post-conditions. The important and main thing in a proposal is the budget needed for the activity, in determining the budget for infrastructure activities such as construction/repairing of neighborhood roads.

Assistance in writing proposals by providing training to calculate the volume of concrete rebate work, namely by calculating the length of the road plan times the width of the road plan times the thickness of the concrete plan, after obtaining the volume of the environmental road construction/repair plan. The next step is to calculate the need for tools and materials by first selecting the type of concrete quality desired, based on funding considerations, to calculate the needs for tools and materials, the guidelines used in calculating material and labor requirements using unit price analysis for infrastructure work in the City of Bandung, by converting the price of the item to be purchased (Sendar 2021). 
After the proposal was drafted, the youth of RT 01 RW 14 invited the community members to a meeting to discuss the preparation of the road repair committee. In the preparation of this committee, youth youth organizations in collaboration with the head of RT 01 RW 14 gave an explanation of the importance of the committee in an activity, because an activity will not run and be successful without a committee. In general, the duties and functions of the committee are a forum that accommodates planning, organizing, implementing, monitoring and evaluating the stages of implementing activities, so that the committee is in charge of regulating the implementation of activities starting from pre-conditions, implementation, to post-activities by monitoring and controlling during implementation of activities. Morally, the committee is responsible for conditioning and creating a conducive and cooperative atmosphere for the implementation of activities, so that the intensity of coordination and communication with all elements involved must always be maintained 21 .

During the socialization of the committee meeting, it was also explained the main duties and functions of the committee itself, so that each person who had been appointed to the committee was responsible for their respective duties, and from the results of the meeting a committee was formed consisting of the chief executive, secretary, treasurer, development section, public relations section, security section, and funding section.

In general, the main tasks and functions of each committee are explained by the youth youth groups, including the Chief Executive in charge of leading the activities so that it goes according to plan with the target of realizing the proposed concrete rebate for the block A RT 01 neighborhood road, the Secretary is in charge of recording all activities that support the smooth running the environmental road concrete rebate process, one of which is making a proposal according to the format applicable at the village level, making a list of prospective donors. The treasurer is in charge of recording and reporting the finances of environmental road repairs from pre-condition to post-condition. For the sections that are in the committee, the main tasks and functions are also explained, namely the Funding Section is in charge of raising funds either to local residents or to potential donors who have been recorded by the secretary. The Development Section is in charge of designing environmental road improvement plans complete with details of the required budget and specifications for the type of building to be implemented. The Public Relations Section (Humas) is in charge of socializing the environmental road repair activities of Block A RT 01 RW 14 Kampung Babakan Cikeruh to the surrounding community and asking for the participation of citizens in terms of thoughts, energy and materials so that road repair planning can be carried out, and the last is the Security Section in charge of regulating the implementation of the improvement of the environmental road block A RT 01 starting from pre-condition to post-conditioning, this

21 Tumpi. Readhouse, "Ingin Membuat Panitia Event? Ini Tugas Dan Tanggung Jawabnya, Kewirausahaan.," Tumpi.Id., last modified 2016, accessed February 22, 2016, https://tumpi.id/inginmembuat-panitia-event-ini-tugas-dan-tanggung-jawabnya/. 
needs to be done because in the process there are pros and cons from the community, so this needs to be immediately secured by always conducting socialization and discussing with the community.

After the proposal is fully structured and known and signed by village officials from the RT, RW and Village Head levels, the next step is the implementation of fundraising. For the method of raising funds, youth youth organizations directly give direction to the committee regarding the sources of funds that can be extracted. Based on the exploration of regional potential, the direction of fundraising is carried out in two directions, namely internal and external, for internal, namely the excavation of funds carried out in the community of RT 01 RW 14 Kampung Babakan Cikeruh by first providing the option to donate in the form of energy, money or in the form of food. , after the readiness of the RT 01 community members appeared, a record was made regarding the self-help donations from the RT 01 community members. Meanwhile, for external fundraising, excavation and fundraising were carried out to outside parties outside the community of RT 01 RW 14 Kampung Babakan Cikeruh through dissemination proposals to several prospective donors/colleagues, several material shops around Kampung Babakan Cikeruh, shopping centers (supermarkets) and office centers around the service location. After raising funds for the construction/repair of the RT neighborhood road, a record is made in the activity treasurer regarding the goods or money that has been received. In the recording, the treasurer is accompanied and directed so that the recording is according to the date of receipt, the aim is that the treasurer does not experience difficulties if there is an excess or reduced amount of money, this must be emphasized considering the habits in the cloud community when managing finances activities are often mixed with personal finances/ family, so it is often a problem for the treasurer.

After the funds are collected and recorded in detail by the treasurer, and it is deemed sufficient, the next step is to hold a committee meeting for the construction/repair of the neighborhood road block A RT 01 with a meeting agenda when the construction/repair of the RT neighborhood road will be carried out. After being mutually agreed upon by the committee regarding the timing of the work, the next step was for youth youth groups to work together with the public relations section to socialize the implementation of the RT neighborhood road construction/repair work. In accordance with the mutually agreed plan, the implementation of road repairs was immediately carried out, by first coordinating with the entire committee regarding the technical implementation of road repair work. In order to avoid confusion in the implementation of the work, the youth youth organizations and the head of RT 01 gave directions regarding the technical work on road construction/repairs and gave strong instructions in appointing and determining who would be the coordinator in carrying out the work, and not necessarily the chief executive, but the person who has a very large 
influence, so that all instructions will be followed and implemented ${ }^{22}$. The purpose of the appointment and determination of this coordinator is that when carrying out work, work instructions only come from one person, so that there will not be many instructions that can interfere with working conditions and confuse workers.

The election of the coordinator for implementing the work to become the regulator and director of the implementation of the work, and based on several complaints from the residents living downstream, several preparations were made, including land clearing, road filling (this was done because considering the location of road construction/repairs is land) which is sloping, and is still in the form of original soil, it is necessary to raise the height of the soil elevation), the technique of backfilling has also changed, especially for the middle part, because in the middle part of the rainy season, it becomes a place that sends a lot of excess water volume, causing flooding in the area. downstream part, and on the basis of these problems, more backfill in the middle part is carried out and is used as a culmination in the construction/repair of RT environmental roads, this decision is based on the direction and assistance of the author by listening to input from the community so that a joint solution is obtained for problems at the service location. In addition to the appointment of the implementing coordinator for the work, the youth youth organizations together with the head of RT 01 and the committee appointed the person in charge of the beneficiaries when the work was in progress, such as the consumption department and the recipient of assistance/donations from local residents, as well as the person in charge when tools and materials were in short supply, so it was necessary to find a solution as soon as possible.

After completing the implementation of the development/repair of the environmental road block A RT 01, the implementing committee of the activity must still be accompanied by the author to make an accountability report for the results of the activities to the community members of RW 14 Kampung Babakan Cikeruh, as a form of accountability both administratively and morally to the community, in addition Accountability reports are very important as evidence of transparency with citizens, so that nothing is covered up, and all citizens have the right to know the amount of funds obtained in the form of goods, money or labor, and then citizens have the right to know how they were used, such as what they spent, where, how much. The amount and physical evidence that can be seen directly by the community about the goods spent. This is mandatory, because the use of money in the community is very sensitive, therefore with the existence of an accountability report for the implementation of activities, all can know clearly and clearly. This accountability report aims to provide information on the implementation and process of running an activity, besides that it can be used as material

22 Kementerian PUPR, Modul 3: Perencanaan Jaringan Jalan Dan Perencanaan Teknis Terkait Pengadaan Tanah, Perencanaan Dan Pengadaan Tanah Untuk Pembangunan Jalan (Bandung, 2017). 
for evaluating an activity because it provides a detailed chronological report of activities so that we will have a measuring tool for the work results and team abilities.

In order for the accountability report for the development/repair of the environmental road RT 01 RW 14 to be accepted by the community, it is necessary to emphasize several things that need to be considered, including the scope of the accountability report which includes reports on the implementation of activities starting from the proposal preparation process, fundraising, implementation of activities. , and preparation of reports. What is very important and needs to be noted to the implementing committee is the report on the use of funds, the reporting method must be systematic, comprehensive and integrated. ${ }^{23}$

\section{Results}

The following describes the results of mentoring and empowerment for youth youths in RT 01 RW 14 Babakan Cikeruh Village in the construction/repair of the neighborhood road block A RT 01 in Participatory Action Research for community service, the first assistance is regarding assistance in recording prospective direct beneficiaries. Assistance in the recording of beneficiaries is very important in planning for village infrastructure, because if its usefulness cannot change a development for the better, then the proposal is not feasible and will not have a significant impact on social dynamics that cover all aspects of life.

In recording the prospective direct beneficiaries, the RT environmental road construction/repair activity committee was directed and explained that the direct beneficiaries included the community members traversed by the RT environmental road, and from the results of data collection based on data from the RW 14 head, it was matched with Based on direct data collection in the field, it was recorded that the total direct beneficiaries were 65 families with a population of 225 people consisting of men, women, children and adults. Meanwhile, the prospective indirect beneficiaries are not recorded because the assumption is that the indirect beneficiaries are all community members outside the RT 01 environment, this can come from other RT areas or other RW areas, or maybe from other villagers who cannot be recorded. in detail, therefore, the author suggests to the committee that the indirect recipients do not need to be recorded and reported.

The next step is assistance in calculating the volume of work from the development/repair plan for the neighborhood road block A RT 01. The initial step is to re-measure the length and width of the road to be built/repaired. The purpose of the remeasurement is to ensure the total material requirements for the construction/repair of the environmental road block A RT 01, and based on the results of field measurements, data is obtained for a road plan of $50 \mathrm{~m}$ and a road width of $3 \mathrm{~m}$. After knowing the length and width of the road, the next step is to determine the thickness of the road to be built/improved, this determination is not made/determined by the head of the RT or

\footnotetext{
23 Aufa Atila, "Cara Membuat Laporan Pertanggungjawaban Kegiatan Yang Baik," Jojonomic.Com/Blog, last modified 2021, accessed January 17, 2021, https://www.jojonomic.com/blog/laporan-pertanggungjawaban/.
} 
youth youth or development section, but is determined by the results of the meeting of community representatives in RT 01 RW 14 and the results of the meeting of community representatives, it is agreed that the thickness of the road is $20 \mathrm{~cm}$, so that the volume of work is $30 \mathrm{~m}^{\wedge} 3$, and taking into account the prediction of the acquisition of fundraising and the type of vehicle that will pass through the road is not a heavy vehicle, then in the meeting based on the author's direction, it was also agreed that the construction/repair of the RT neighborhood road using concrete rebates n K175 concrete quality. The results of the re-measurement and calculation of the volume of the work plan, the following is obtained documentation of road conditions of $0 \%$.
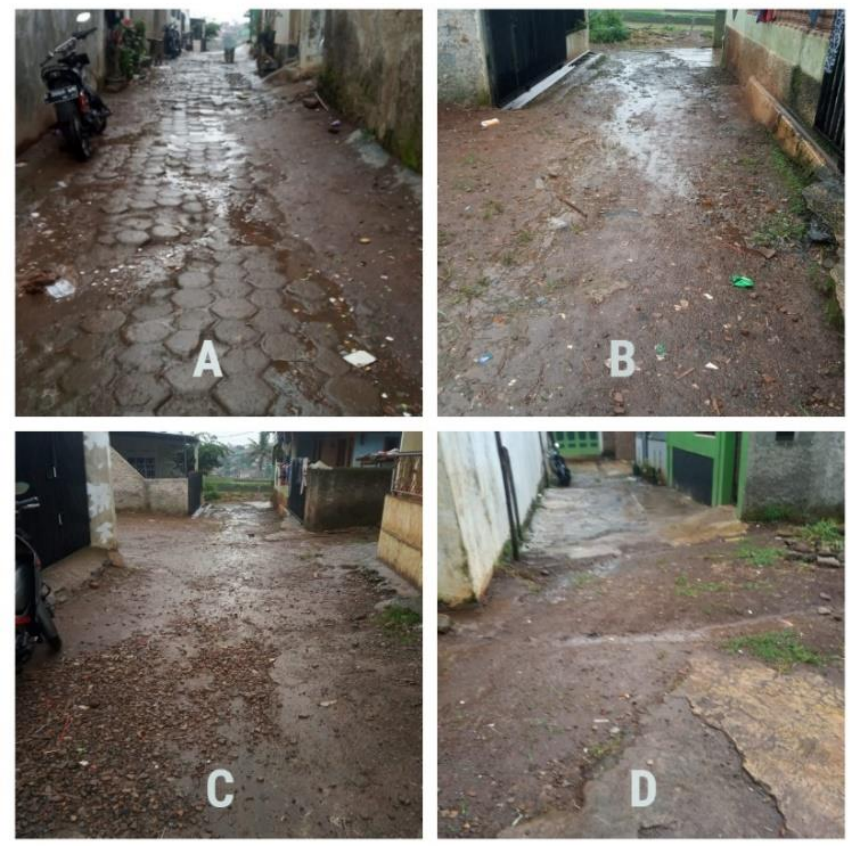

Figure 3. 0\% Condition of Environmental Roads RT 01 RW 14 Babakan Cikeruh Village, (A) Upstream Section of the Road, (B and C) Middle Section of the Road, (D) Downstream Section of the Road.

In addition to planning and calculating the volume of road construction/repairs, the activity implementing committee is faced with a problem that is part of the RT environmental road construction/repair, and if this problem is immediately found a solution, it will become a problem in the future even though the condition of the block $\mathrm{A}$ neighborhood road RT 01 is good and decent. The problem is the disposal of household wastewater near the road to be built/repaired, this household wastewater comes from 6 families. If not handled immediately, this waste water will contaminate and cause various problems, namely environmental pollution and can also lead to being a source of disease and become a nest for mosquitoes. The results of the meeting of residents, youth youth organizations and the committee, it was agreed that the solution for household waste water was by making infiltration wells, these infiltration wells functioned to accommodate household wastewater which was then absorbed into the ground ${ }^{24}$, other

${ }^{24}$ Kementrian Kesehatan RI, Pembuatan Saluran Pembuangan Air Limbah (SPAL) Sederhana (Jakarta, 
than as a disposal site. waste water and rainwater runoff, this infiltration well can be used as an artificial recharge for the residents' wells around the road block A RT 01, because at the peak of the dry season the condition of well water is very scarce. Based on the author's direction, it was agreed that the dimensions of the infiltration well planning are $1.3 \mathrm{~m}$ long, $1.3 \mathrm{~m}$ wide and $1.5 \mathrm{~m}$ high.

After the volume of work is known, the youth youth groups together with the committee for the construction/repair of the environmental road block A RT 01 will calculate the total need for tools and materials. In this calculation, the priority is the calculation of the total material requirements because all the equipment comes from every resident who will work bringing their own equipment such as hoes, scoops, buckets, cement spoons, crowbars, digging crowbars. In addition to the need for tools and materials, the total need for labor, both builders and workers (laden) also needs to be calculated, and using the reference from the 2020 Bandung City Wage and Material Work Unit Price List ${ }^{25}$, choose the reference for the Wage and Material Work Unit Price List and The material from the city of Bandung is because the location of the service is closer to the border of the city of Bandung and the character of the price of materials, the price of wages and the price of tools is more likely to be similar to the area of the city of Bandung, and the results obtained are the results of the need for tools and materials as listed in table 2 below

Table 2. Total Need for Tools, Materials and Labor

\begin{tabular}{clr}
\hline No & \multicolumn{1}{c}{ Materials needs } & \multicolumn{1}{c}{ Total Needs } \\
\hline 1 & Measurement Tools & $77,12 \mathrm{ls}$ \\
\hline 2 & Wood 3m & $5,9 \mathrm{~m}^{3}$ \\
\hline 3 & Spike 5-7 & $3,9 \mathrm{~kg}$ \\
\hline 4 & Cements & 204 packs \\
\hline 5 & Sand & $16,2 \mathrm{~m}^{3}$ \\
\hline 6 & Gravel & $24,9 \mathrm{~m}^{3}$ \\
\hline 7 & Iron Frame 8 & $1 \mathrm{pcs}$ \\
\hline 8 & Wire & $1 \mathrm{roll}$ \\
\hline 9 & Blocks & $75 \mathrm{pcs}$ \\
\hline 10 & Pipes & $6 \mathrm{pcs}$ \\
\hline 11 & Knee plumb & $1 \mathrm{pcs}$ \\
\hline 12 & Builders & 17 person \\
\hline 13 & Workers & 48 person \\
\hline
\end{tabular}

Source: researchers, 2021

Based on table 2, it can be calculated the total need for funds for repairing the environmental road RT 01 RW 14 Kampung Babakan Cikeruh as shown in table 3 below

2020).

25 Dinas Keciptakaryaan dan Pertamanan Kota Bandung, Daftar Harga Satuan Pekerjaan Upah Dan Bahan Kota Bandung (Kota Bandung, 2020). 
Tabel 3. Recapitulation of Total Fund Needs for Environmental Road Repair Work RT 01 RW 14 Babakan Cikeruh Village

\begin{tabular}{rlr}
\hline No & \multicolumn{1}{c}{ Activities } & Total Cost (IDR) \\
\hline 1 & Remeasurement work & 637.500 \\
\hline 2 & Bowplang Installation Work & 89.750 \\
\hline 3 & Safety Fence Work & 843.000 \\
\hline 4 & Cast Concrete Site Mix K 175 & 25.347 .000 \\
\hline 5 & Infiltration wells & Total \\
\hline & & 27.498 .782 \\
\hline
\end{tabular}

Source: researchers, 2021

The results of the above recap serve as a reference for the event organizing committee to dig up funds for donors, by first separating the types of financing from nongovernmental organizations around the community and financing from outside parties. In accordance with the agreement taken together based on consensus, namely the cost of equipment and labor is self-supporting, then the total need for funds that must be collected is Rp. 18,834,000,- (Eighteen Million Eight hundred Thirty Four Thousand Rupiah) with details as shown in table 4 below

Table 4. Total Funding Needs Based on Tools, Materials and Labor

\begin{tabular}{|c|c|c|}
\hline $\mathrm{No}$ & Needs & Total Cost \\
\hline 1 & Equipments & 1.162 .600 \\
\hline 2 & Materials & 18.834 .307 \\
\hline \multirow{2}{*}{\multicolumn{2}{|c|}{3 Workers }} & 7.501 .875 \\
\hline & & 27.498 .782 \\
\hline
\end{tabular}

Source: researchers, 2021

The results of the assistance in calculating the volume of work and material needs are then poured into a proposal for proposed activities. With the preparation of proposals for activities to assist the committee in the implementation of excavation/fundraising (Fauzia 2014), the next step is to raise funds by referring to the potentials possessed by the area around the service location. Fundraising/raising is carried out independently in two directions, namely first, self-help from internally within the community of RT 01 RW 14 Kampung Babakan Cikeruh and the second is self-help from external sources, namely collecting funds from outside the neighborhood of RT 01. Fundraising internally is obtained data on the willingness of residents to give their energy for free to work together in the construction/repair of RT neighborhood roads, in addition there is the willingness of community members from RT 01 RW 14 who are willing to provide consumption when the work is carried out. External fundraising was carried out to several people who were considered to have adequate financial capabilities, including material shop owners, property developers, and several colleagues from residents of RT 01 RW 14 Kampung Babakan Cikeruh. The results of fundraising from external were obtained from donations 
in the form of goods such as 2 trucks of concrete sand, 1 truck of split, 60 bags of cement. This is a trigger and impetus for residents to be able to meet the overall material needs.

With the collection of funds for financing the construction/repair of RT environmental roads, and then spending on goods and materials, the implementation of the work is immediately carried out, to determine the time for the implementation of the construction/repair of RT environmental roads, youth youth groups, together with the RT management, the activity implementing committee and community members hold meetings. On the basis of input and suggestions from the head of the RT and all members of the community in RT 01, it was agreed that the results of the meeting for the implementation of the work were decided to be carried out on Sundays. for the infiltration well work carried out a few days before the implementation of the construction/repair of the RT neighborhood road, this is intended so that when the road concrete is carried out the condition of the infiltration well is strong and ready, so it is not damaged because the infiltration well position is under the road to be built.

Based on mutual agreement, the first work to be done is to make an infiltration well with a position located at the mouth of the alley, the dimensions of the infiltration well are $1.3 \mathrm{mx} 1.3 \mathrm{mx} 1.5 \mathrm{~m}$, as a filter material in the infiltration well using fine sand as high as $20 \mathrm{~cm}\left(\mathrm{~V}=0.338 \mathrm{~m}^{\wedge} 3\right)$ and the split is $20 \mathrm{~cm}$ high $\left(\mathrm{V}=0.338 \mathrm{~m}^{\wedge} 3\right)$, and red brick is installed on the top (wall) as high as $40 \mathrm{~cm}\left(\mathrm{~V}=2.08 \mathrm{~m}^{\wedge} 2\right)$. As a cover used reinforced concrete with reinforcement $8,12 \mathrm{~cm}$ thick. The following is some documentation of the implementation of the environmental road repair work in block A RT 01 RW 14 Babakan Cikeruh Village, as follows.
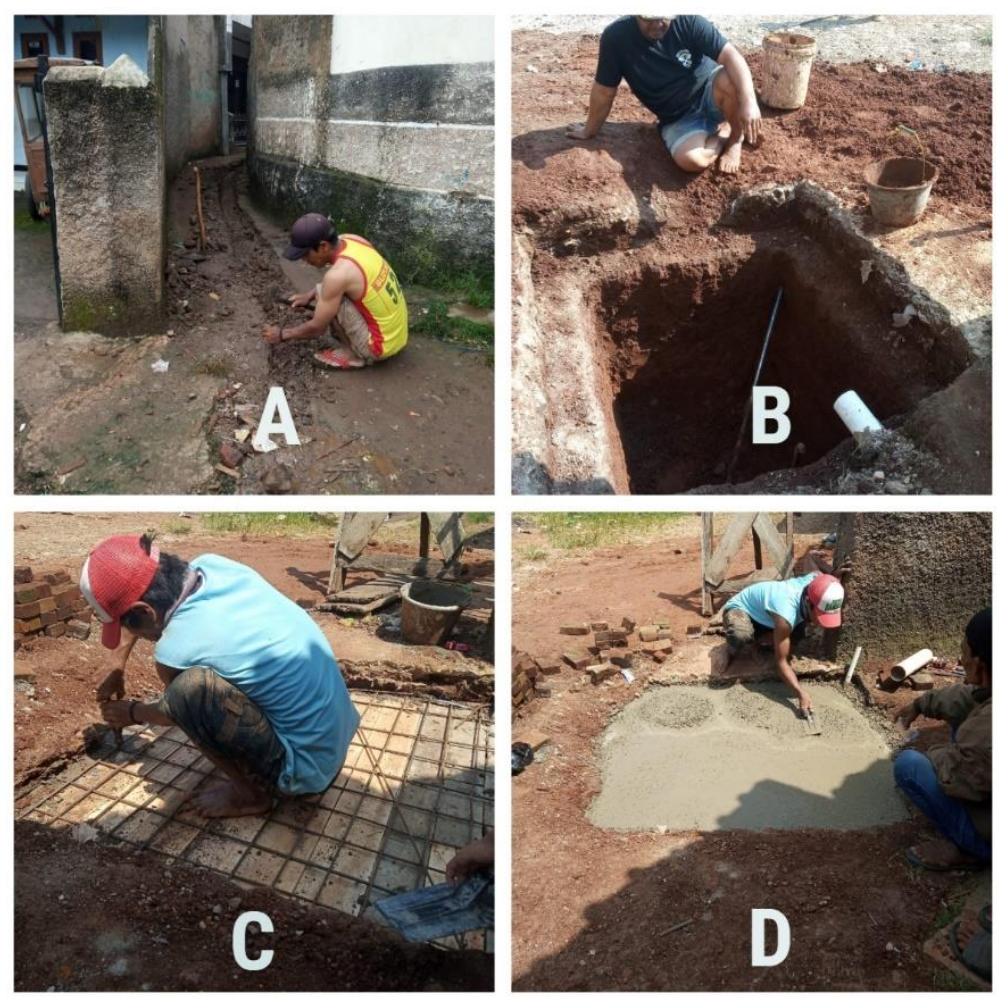

Figure 4. The process of making infiltration wells (A) the process of making sewers,

$(B)$ the process of digging infiltration wells, $(C)$ working on ironing infiltration wells, (D) working on closing (concrete) 
After the infiltration well is closed and the concrete cover has hardened, the next step is the implementation of the construction/remediation of environmental roads using concrete rebates. Based on the agreement and direction from the field coordinator, the construction/repair of environmental roads using concrete rebates is carried out in several stages, including land preparation and clearing, backfilling and leveling of roads, concrete $^{26}$.

In the process of land preparation and clearing, the work carried out is land clearing, so that the boundaries of the road to be repaired are clear, in addition to knowing the elevation of the road, so that we will know which parts have to be filled and which parts are flat.
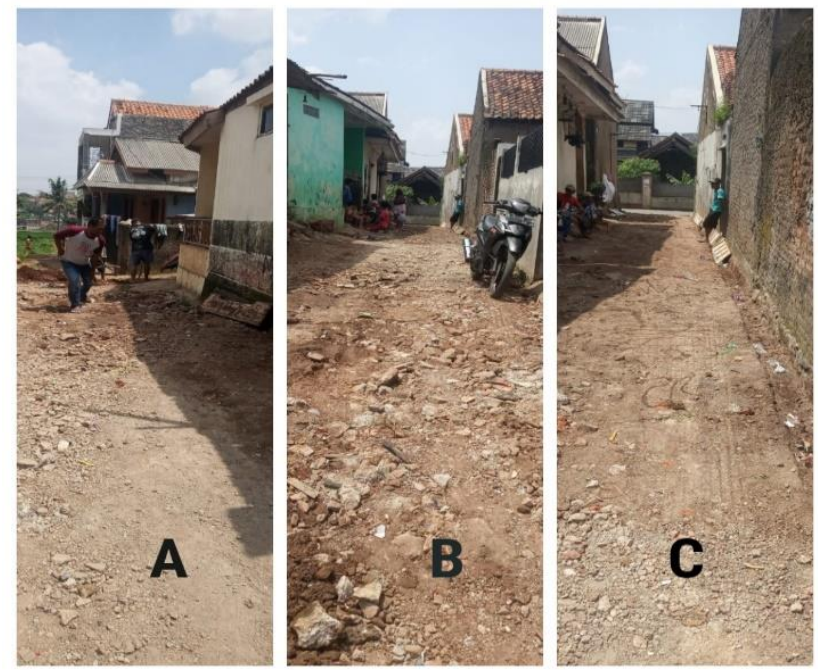

Figure 5. The process of road clearing $(A)$ the results of land clearing on the downstream road, $(B)$ the results of land clearing on the middle road, $(C)$ the results of land clearing on the upstream road.

After clearing the land, backfill is carried out using brangkal (remaining material from construction from other places), after filling it is then leveled according to the results of the elevation measurement.

26 “(Eprocurement), Pengadaan. 'Apa Itu Rabat Beton? Ini Tahapan Pembangunannya.,"' Www.Pengadaan.Web.Id., last modified 2020, https://www.pengadaan.web.id/2020/10/rabat-betonjalan-desa.html. 

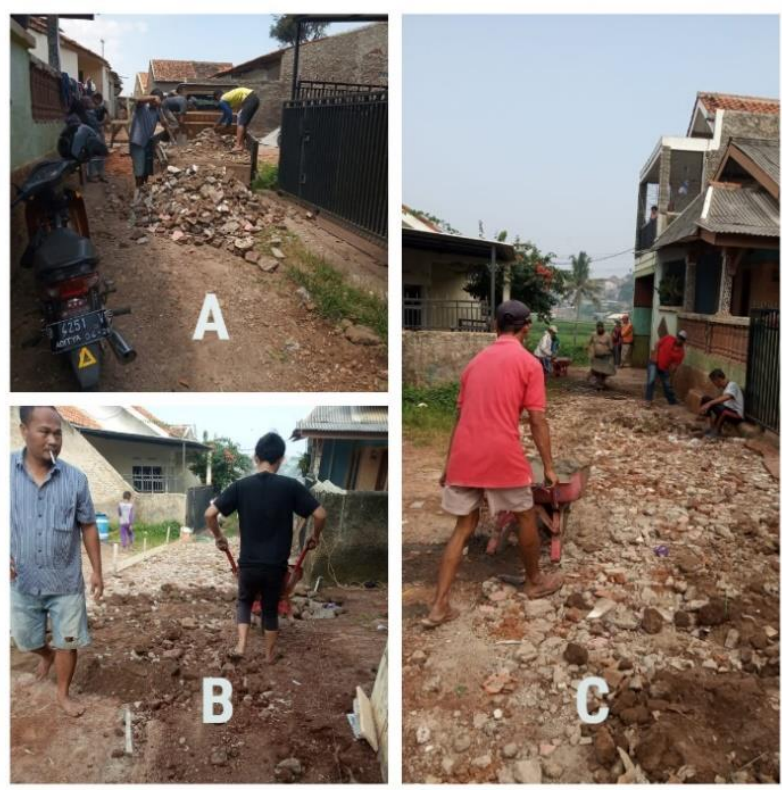

Figure 6. Backfill and Road Leveling Process (A) backfill for middle to downstream roads,

(B) backfill for upstream roads, (C) backfill for middle roads (peak point of rainwater diversion)

The process of implementing the construction/repair of the environmental road block A RT 01 with concrete rebates starts from the back of the repair site, this is done because it takes into account several things, including different height positions, where the back is lower; and to facilitate access in and out of material.
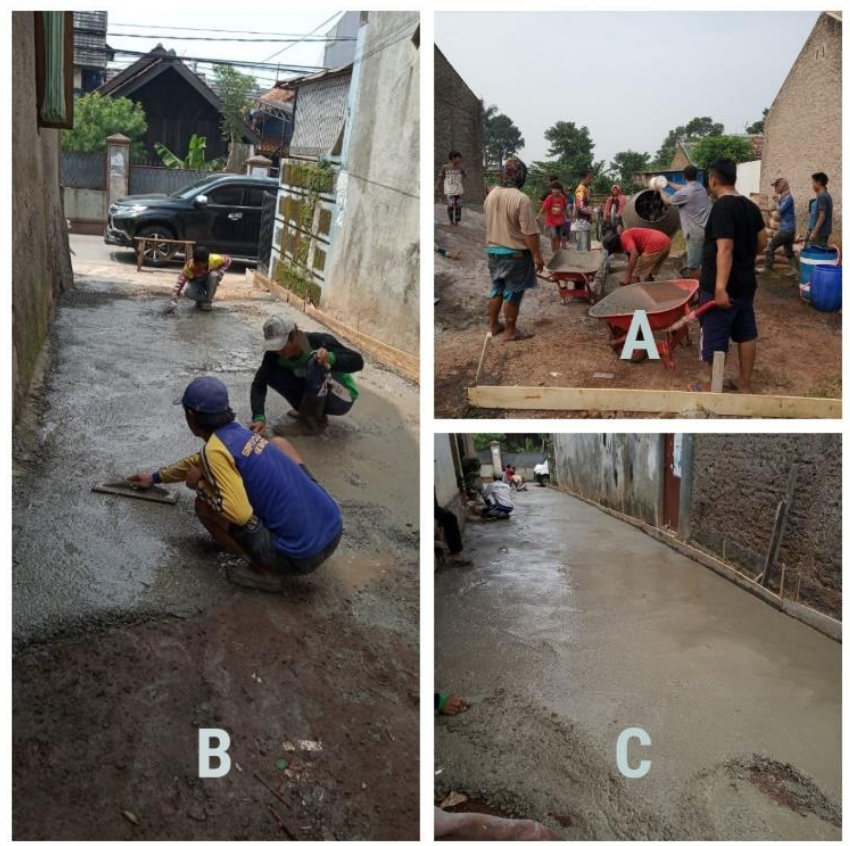

Figure 7. The process of implementing road concrete (A) the process of making concrete with a manual concrete mixer, $(B)$ the process of leveling the concrete mix, $(C)$ the condition of the concrete after it has been leveled. 
After the rear is completed, it is continued with concreting from the front, this is done to take the peak point of the road height, this is done because it is to divert the flow of water when there is heavy rain, where when it rains heavily, rainwater runoff will go directly downstream, resulting in houses When it rains heavily, this condition is exacerbated by the unavailability of adequate drainage channels, so that runoff from the alley is dumped into the original dirt road, resulting in erosion and houses downstream from rain runoff. With the availability of flow paths with drainage, the volume of rainwater runoff is quite drastically reduced. The longitudinal section of the road and the determination of the elevation of the road in the middle can be seen in the following figure.
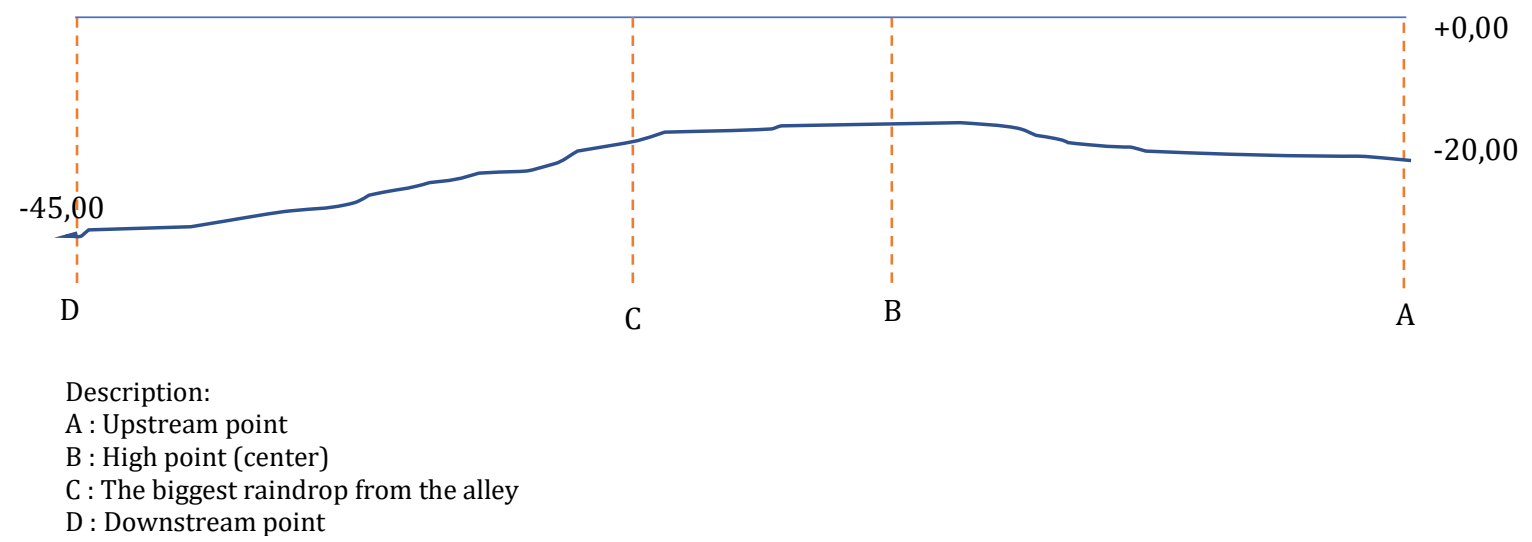

Figure 8. Initial position elevation elevation of road surface

Based on Figure 6 above, it can be explained that the initial conditions when it rains, rainwater from point $B$ flows to point $A$, and rainwater from point $C$ flows downstream (point D) with a fairly large volume and discharge. To reduce the volume and discharge of water from point $\mathrm{C}$ When it rains heavily, the committee builds an embankment at point $C$, assuming that rainwater will flow to point A (upstream), this is done because at point $A$ there is a drainage channel, so the water rain from point $C$ will be wasted directly into the drainage channel. The results of these changes can be seen in the longitudinal section of the road in Figure 7 below.

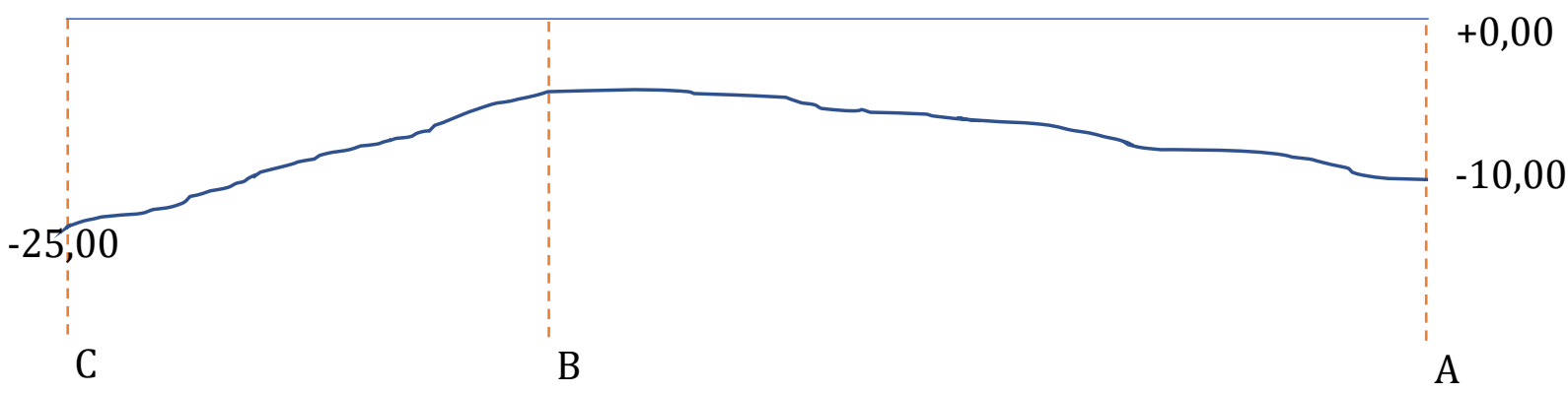

Description

A : Upstream point

B : High point (center)

$\mathrm{C}$ : Downstream point

Figure 9. The position of the elevation of the road surface after experiencing a change 
The change in elevation at point $C$ to point $B$ has an effect on other parts, namely an elevation of the alleyway as high as $30 \mathrm{~cm}, 6 \mathrm{~m}$ long and $1.2 \mathrm{~m}$ wide. this is done so that when it rains, the overflow of rainwater will easily flow directly to point $A$. The running of this activity cannot be separated from the agreement of the residents in carrying out activities with a field coordinator who has influence, so there are no disputes and debates when carrying out the work. After the implementation of the environmental road construction/repair work has been completed, it is concluded that in general the results of the RT environmental road construction/repair using concrete rebates are proceeding according to plan, and the following results of the work can be seen in figure 10 below.

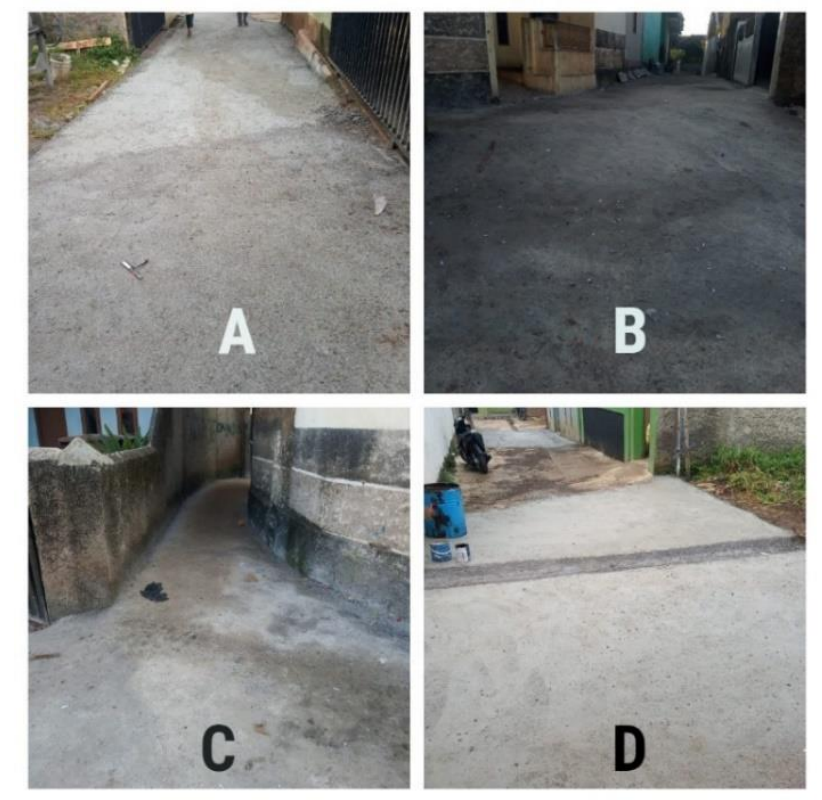

Figure 10. The condition of the neighborhood road in RT 01 RW 14 Kampung Babakan Cikeruh after repair $(A)$ the location of the road from the middle to the downstream of the road, $(B)$ the location of the road from the middle to the upstream of the road, $(C)$ the location of the alley, (D) the location of the road downstream.

Good coordination and cooperation between all elements involved in the process of building/repairing the environmental road block A RT 01 with concrete rebates can be used as a benchmark in assistance at service locations, but this still needs further assistance in the form of preparation of Accountability Reports, because After the work is $100 \%$ complete, the activity implementing committee is obliged to report the results of its work to all community members, the head of the RT, the head of the RW and the village head as a form of accountability both administratively and morally. In the preparation step of the accountability report for this activity, the committee was accompanied by youth youth groups, so that the committee was indirectly taught how to prepare an accountability report, and what things needed to be reported.

In preparing the accountability report, the data that needs to be collected is data 
on the acquisition of self-help funds including a complete list of the number of donors with the types donated in the form of money or goods, complete with the nominal amount. After all lists of incoming funds have been recorded, the next data is a record of the expenditure of the use of funds accompanied by proof of transactions in the form of notes/bonds and receipts, after the proof of expenditure is complete, a financial report is prepared, so that the final result of the financial report will be known, whether there is a balance, or balance, or even there are arrears in the material shop, and to complete the accountability report, the committee needs to collect activity documentation starting from the $0 \%$ condition, $50 \%$ condition to $100 \%$ condition, the goal is to see the difference between the three, so that after the work is finished then with documentation will indirectly explain to the community that the results of the work of the implementing committee of activities are feasible or not, so that they can be used as evaluation material for the next activity.

\section{Discussion}

Kampung Babakan Cikeruh is one of the villages that is included in the administrative area of Cimekar Village, Cileunyi sub-district, Bandung district, some of the problems faced are very complex and must be solved. Problems will be easily resolved if they are slowly resolved in a sequential and orderly manner, because problems in the community require a lot of awareness, energy and thought. Solving this problem requires a high level of community participation, resulting in a very high sense of belonging to the territory and if this community participation is established regularly and also regularly and institutionally, then the desired social change goals will be easily realized ${ }^{27}$, as happened in RT 01 RW 14 Kampung Babakan Cikeruh, where the problem faced is the desire to have a decent neighborhood road, but there is no allocation of funds from the government, so it is necessary to carry out a participatory movement to explore self-help. One of the drivers of very productive participation in society is that youth youth organizations and youth youth organizations have enormous potential and if properly directed and guided, their potential will be channeled properly. One of the potentials that must be directed is the potential to develop the territory, and one way to develop the territory is through the improvement of the environmental road block A RT 01 RW 14 Kampung Babakan Cikeruh.

Youth as the driving force of change has a vital role, because as Agents of Change, therefore, youth must be sure of the abilities they have and can be used as best they can to do good together properly and correctly. In addition, youth are also agents of

27 Lukas Y Sonbait and Yustina L D Wambrauw, "Permasalahan Dan Solusi Pemberdayaan Masyarakat Melalui Program Biogas Sebagai Energi Alternatif Di Kabupaten Manokwari Papua Barat (Problems and Solutions Program for Community Empowerment through Biogas as an Alternative Energy at Manokwari Regency We," Jurnal Ilmu Ternak Universitas Padjadjaran 11, no. 2 (2011). 
development because youth have a very big responsibility in carrying out and succeeding in development, both at the regional and national levels, so that the potential and productivity of the younger generation are needed to the fullest. Another role of youth is as Agent of Modernizations, because the ability to analyze the changing times is mandatory for youth, such as the development and advancement of technology today which has a very big influence on the world, and so that the role of youth can function optimally, it is important What must be owned by youth is education, because with education it opens all world horizons, education can be obtained formally and informally. Talking about education in RT 01 RW 14, Babakan Cikeruh village is very sensitive, because they still think that education is a high degree certificate, in general it is true, but if the problem lies in economic limitations, of course it will be the main obstacle in pursuing higher education, because The education that we must emphasize at this community service location is education outside of $\operatorname{school}^{28}$.

Formal education must be taken at educational institutions that are legally valid, such as schools or universities, but if this happens to youth over the age of 17 , it will be difficult to answer and explain the importance of education for life. This fact makes us have to think hard so that the Participatory Action Study research can proceed according to the plan and according to the expectations of the community members of RW 14 Kampung Babakan Cikeruh, so the steps taken are to collaborate with youth youth organizations and the head of the RT to assist the community members in receiving new information. , especially for youth so that youth will be able to understand which information is suitable for consumption and useful for the surrounding community. In assisting youth youth organizations at the service location, the author also collaborates with elder community leaders and religious leaders, as well as youth leaders, this is important because if you convey directly to community members without involving leaders, the reception will be different, because maybe it will only be considered as only a theory, but if it is accompanied by elder and respected figures, then the information that will be conveyed will be faster to the community members.

The Participatory Action Study method used at the mentoring location is using the explanative type, which facilitates community members at the service location to participate in analyzing needs, problems and solutions, so that a transformative action plan can be described ${ }^{29}$. Based on this type, data collection is carried out by sharing experiences with community members, RT heads, youth youth organizations and several elder and respected figures. One of the types of sharing experiences/stories conveyed by the author is the role of youth in regional development because actually regional development is not only the task of the head of the RT but a joint task. At first it was very

28 Aditya Rangga, "Peran Pemuda Sebagai Penerus Bangsa," Cerdika.Com, last modified 2020, accessed September 27, 2020, https://cerdika.com/peran-pemuda-sebagai-penerus-bangsa/.

29 Fajar Junaedi, Participatory Action Research, Metode Riset Untuk Analisis Sosial Partisipatif (Yogyakarta: Ilmu Komunikasi, Universitas Muhamadiyah Yogyakarta, 2019). 
difficult to convince the community members and youth, because they were already inferior because of their low level of education, but with persistence and enthusiasm that education was low but had experience, they lived to be directed and guided regularly, then what they wished for would be easily realized, finally the community members and the youth of RW 14 Kampung Babakan Cikeruh were moved.

Through this community service program, the youth of RW 14, Babakan Cikeruh village, are invited to jointly plan development independently, and what is done is to provide training and assistance on how to realize environmental road improvements with concrete rebates and of course by paying attention to the psychological factors of local residents. , economic factors and cultural factors because the construction/repair of environmental roads is a shared task and must be completed together, from this training youths seek the potential for raising funds from the community through meetings with the community, so that they are aware and fully understand the ability of funds that can be obtained by the community around the location road repair. After mapping and recording the possible financial capacity of the community at the repair site, the youth youth group of RW 14 tried to find additional sources of funding from outside parties as the main addition, and the output produced was a list of donors for the environmental road repair activity in block A RT $01^{30}$.

After the youth can map the sources of funds from internal and external, the next step is planning the preparation of environmental road construction. At this stage, training and mentoring are carried out to the youth of Kampung Babakan Cikeruh on how to plan road construction, which includes the type of road repair that the community members of RT 01 want, calculating the volume of work including what type of work will be carried out, calculating the total need for tools and materials as well as work costs, compiling a Budget Plan in order to obtain data on the total need for funds, extracting/raising funds and routine coordination related to the achievement of fundraising, this is mandatory because as a benchmark when development will begin, implementation and accountability reports, at this stage is to provide knowledge to the youth that when the work process needs a documentation, a report on the use of funds as material for an accountability report, as proof of transparency to the community. Based on the explanation above, the process of transferring knowledge to the community members and youth of RW 14 Kampung Babakan Cikeruh is to encourage the youth to want to learn in developing their territory and encourage the community members to fully support (both materially and morally) what has been prepared and planned by the youth.

30 Wahyudin Kessa, "Perencanaan Pembangunan Desa," Jakarta: Kementerian Desa Pembangunan Daerah Tertinggal Dan Transmigrasi Republik Indonesia (2015). 


\section{Summary}

Youth empowerment of RW 14 youth organizations for regional development is very important because youth are the motor of a change, development and moderation of a nation. This potential must be guided and directed so that the role of youth youth organizations in development becomes real, one example of the role of youth youth organizations in RT 01 RW 14 Kampung Babakan Cikeruh in planning and implementing environmental road repairs in block A of RT 01 with concrete rebates. The planning and implementation process is carried out in stages, starting from socialization to community members and youth youth groups regarding their role for the region. For infrastructure development in the RT area, the role of youth youth in RW 14 Kampung Babakan Cikeruh is very much needed, where their important roles are exploring the potential of the region based on regional characteristics. The importance of exploring this potential is the basis for a strong reason why the construction/repair of the environmental road block A RT 01 needs to be carried out, and because the fund for the development/repair plan of this environmental road is not sourced from the government, in exploring the potential of the area here it is also necessary to map the potential for extracting development funds from the government the area around RW 14.

To find out how much funding is needed from the planning for the construction/repair of the environmental road block A RT 01, the volume of work is calculated, so that it can be seen how much material, equipment and manpower needs are needed, so that the committee can measure the total cost that must be prepared. After the regional potential and total needs are compiled, and then outlined in the proposal, the next step is to extract funds by utilizing the potential of the existing area, both the potential of natural resources and the potential of human resources. After the funds have been dug and collected, planning for the implementation of the work is carried out by taking into account the right time for all residents, so that during implementation, most of the community members around the block a neighborhood of RT 01 can be involved.

The implementation of the construction/repair work for the environmental road block A RT 01 with concrete rebates was carried out in two stages, namely making infiltration wells as artificial recharge and then continuing with road concrete, the two works were carried out on different days because the structure of the infiltration well had to harden first, after it was deemed strong enough, the new road concreting work can be carried out. The implementation of the concrete work takes 1 working day and after the work is completed the committee is required to compile an activity accountability report which is then reported to the community as proof of transparency and becomes an evaluation material for the activities that have been carried out. This proves that, when high willpower is coupled with hard work, it will bear fruit, so that the dream of having a decent neighborhood street can be realized.

The realization of an environmental road in block A of RT 01 by involving the 
participation of all community members in collaboration with the youth of RW 14 proves that a goal will be easy to achieve and help each other. The role of the youth of the RW 14 youth group is very important because they are the main driving force, and from this result it proves that many opportunities in youth must be filled with activities that are profitable for the region. Youth activities in organizations can have a positive impact both for the community and for the region, and from the results of mentoring and empowering youth youth groups in RW 14 youth organizations know how to plan for regional development, especially in the field of infrastructure, starting from how to plan and prepare proposals, then dig up funds by utilizing the potentials that are owned around the area, if the funds have been collected, the youth youth groups can decide when to carry out the work by adjusting the readiness of all residents. The results of the implementation of the work must be administratively accounted for, the goal is that there is transparency to the community, and from the importance of the preparation of this accountability report, the youth of Karang Taruna RW 14 are taught that when an activity has been completed, it needs to be reported legally so that the results of the youth's performance can be measured.

The outcome of the mentoring and empowerment of youth youth groups in RW 14 Babakan Cikeruh Village, Cimekar Village, Cileunyi District, Bandung is the realization of the construction/repair of the environmental road block A RT 01 with concrete rebates as far as 50 meters, 3 meters wide and $20 \mathrm{~cm}$ thick.

\section{Acknowledgements}

The authors thank the Head of Cimekar Village, the administrators of RW 14 and RT 01 of Kampung Babakan Cikeruh for all their cooperation and participation, so that this program can run well, and the author also conveys to the Youth Organizations of RW 14 Kampung Babakan Cikeruh, by taking part in the youth organizations In this program, it gives a separate assessment to the youth of Babakan Cikeruh village. The potential of youth and regions that need to always move dynamically for regional development needs to always be improved, because the progress of the region lies in the hands of the youth, in this case the youth of Kampung Babakan Cikeruh.

\section{References}

Adji, Riyanto. "Pemanfaatan Sampah Non Logam Untuk Metode Artificial Recharge." In In Monograph, Edited by President University Press, 21-22. Bekasi, West Java: President University, 2020.

Afandi, Agus, Mohammad Hadi Sucipto, and Abdul Muhid. Modul Participatory Action Research (PAR) Untuk Pengorganisasian Masyarakat (Community Organizing). 
Lembaga Penelitian dan Pengabdian kepada Masyarakat, UIN Sunan Ampel Surabaya, 2016.

Atila, Aufa. "Cara Membuat Laporan Pertanggungjawaban Kegiatan Yang Baik." Jojonomic.Com/Blog. Last modified 2021. Accessed January 17, 2021. https://www.jojonomic.com/blog/laporan-pertanggungjawaban/.

Badan Pusat Statistik Bandung. Cileunyi Regency In Figures 2020. Bandung: Badan Pusat Statistik Kabupaten Bandung, 2020.

BPD Desa Sindangraja. Contoh Proposal Peningkatan Infrastruktur Perdesaan (Bantuan Provinsi Jawa Barat TA 2012). Jawa Barat, 2012.

Dinas Keciptakaryaan dan Pertamanan Kota Bandung. Daftar Harga Satuan Pekerjaan Upah Dan Bahan Kota Bandung. Kota Bandung, 2020.

Elden, Max, and Rupert F Chisholm. "Emerging Varieties of Action Research: Introduction to the Special Issue." Human relations 46, no. 2 (1993): 121-142.

GreatDayHR. “Ini Pentingnya Laporan Pertanggungjawaban.” (Info\&Update), 2020.

Junaedi, Fajar. Participatory Action Research, Metode Riset Untuk Analisis Sosial Partisipatif. Yogyakarta: Ilmu Komunikasi, Universitas Muhamadiyah Yogyakarta, 2019.

Karsidi, Ravik. KAJI TINDAK: Bentuk Aplikasi Pemberdayaan Masyarakat Oleh Perguruan Tinggi. Surakarta: UNS (Sebelas Maret University), 2008.

- - - "Paradigma Baru Penyuluhan Pembangunan Dalam Pemberdayaan Masyarakat." Mediator: Jurnal Komunikasi 2, no. 1 (2001): 115-125.

Kementerian Pekerjaan Umum dan Perumahan Rakyat. Petunjuk Pelaksanaan Program KOTAKU Tingkat Kelurahan/Desa. Jakarta, 2018.

Kementerian PUPR. Modul 3: Perencanaan Jaringan Jalan Dan Perencanaan Teknis Terkait Pengadaan Tanah, Perencanaan Dan Pengadaan Tanah Untuk Pembangunan Jalan. Bandung, 2017.

Kementrian Kesehatan RI. Pembuatan Saluran Pembuangan Air Limbah (SPAL) Sederhana. Jakarta, 2020.

Kessa, Wahyudin. "Perencanaan Pembangunan Desa." Jakarta: Kementerian Desa Pembangunan Daerah Tertinggal Dan Transmigrasi Republik Indonesia (2015).

McKay, Judy, and Peter Marshall. “The Dual Imperatives of Action Research.” Information Technology \& People (2001).

Mertayasa, Gede Mangku. "Peran Pemuda Dalam Pembangunan." Kesejahteraan Rakyat Pemerintah Kabupaten Buleleng. Buleleng, November 2020. 
Monicha, Vhera. “5 Peranan Pemuda Indonesia Sebagai Generasi Penerus Bangsa." LPMGS UNSRI (LPMGS UNSRI). Palembang, 2019.

Prasetyo, Dicky Eko. "Pemuda Transformatif Untuk Mewujudkan Indonesia Emas Tahun 2045." ResearchGate, 2020.

Rangga, Aditya. "Peran Pemuda Sebagai Penerus Bangsa." Cerdika.Com. Last modified 2020. Accessed September 27, 2020. https://cerdika.com/peran-pemuda-sebagaipenerus-bangsa/.

Readhouse, Tumpi. "Ingin Membuat Panitia Event? Ini Tugas Dan Tanggung Jawabnya, Kewirausahaan.” Tumpi.Id. Last modified 2016. Accessed February 22, 2016. https://tumpi.id/ingin-membuat-panitia-event-ini-tugas-dan-tanggungjawabnya/.

Rijal, Muhammad. "Metode Perencanaan Partisipatif Dalam Membangun Masyarakat." Academia (Academia.Edu), 2019.

Riskita, Amelia. "Cara Mengatasi Kecanduan Gadget Pada Remaja, Orang Tua Wajib Tahu! Informasi Diatas Lima Tahun.” Orami.Co.Id. Last modified 2021. orami.co.id.

Siswanda, and Hetifah Sjaifudian. "Kemajuan Teknologi Sebagai Katalisator Pergerakan Pemuda Di Era Digital." Hetifah.Id (Hetifah.Id). Last modified 2019. hetifah.id.

Sonbait, Lukas Y, and Yustina L D Wambrauw. "Permasalahan Dan Solusi Pemberdayaan Masyarakat Melalui Program Biogas Sebagai Energi Alternatif Di Kabupaten Manokwari Papua Barat (Problems and Solutions Program for Community Empowerment through Biogas as an Alternative Energy at Manokwari Regency We." Jurnal Ilmu Ternak Universitas Padjadjaran 11, no. 2 (2011).

Tampubolon, Rambo Cronika. "Participatory Action Research (PAR).” LBH Jakarta. Last modified 2013. https://bantuanhukum.or.id/participatory-action-research-par/.

“(Eprocurement), Pengadaan. 'Apa Itu Rabat Beton? Ini Tahapan Pembangunannya.'” Www.Pengadaan.Web.Id. Last modified 2020. https://www.pengadaan.web.id/2020/10/rabat-beton-jalan-desa.html.

"Milenial Menjadi Kunci Kesuksesan Ekonomi Digital. Ekonomi Bisnis." Koran Sindo. Last modified 2019. Sindonews.com. 